\title{
Jack pine establishment in Ontario: 5-year comparison of stock types \pm bracke scarification, mounding, and chemical site preparation
}

\author{
by R.F. Sutton and T.P. Weldon
}

Field experimentation was begun in 1984 to assess performance of jack pine (Pinus banksiana Lamb.) $(2+0$ bareroot and FH408 Japanese paperpot) in relation to mechanical site preparation, including Bracke scarification with and without supplementary mounding, and site preparation using Roundup ${ }^{\circledast}$ herbicide. Twenty treatments encompassed 4480 trees in 40 -tree plots split equally between bareroot and paperpot stock. The study site, about $200 \mathrm{~km}$ north of Sault Ste. Marie, Ontario, had deep silt loam soil. After 3 growing seasons, survival was significantly higher among bareroot than among paperpot stock, but survival no longer differed significantly $(P<0.05)$ between stock types 2 years later. In years 4 and 5 , the rate of increase in mean total height of bareroot stock was $11 \%$ less than that of paperpot stock, though bareroot stock was 40 and $4.7 \mathrm{~cm}$ greater in mean total 5th-year height and 5th-year height increment, respectively. Paperpot stock needed mechanical site preparation more than did bareroot stock. By the end of year 5, positive responses of survival and growth to mounding had become clear in both stock types; however, although mound size had little or no effect on survival or total height, mean stem volume was significantly $(P<0.01)$ greater on 20 - $\mathrm{L}$ vs. 10 -L mounds. Fifth-year mean stem volume was also significantly $(P<0.01)$ greater on mineral-on-organic $(\mathrm{M} / \mathrm{O})$ than on mineral-on-mineral (M/M) mounds. Chemical site preparation had no effect on relative growth rates beyond year 3 . Indices that combined survival with total height or stem volume after 5 years show the significant $(P<0.01)$ superiority of: 20 -L vs. $10-\mathrm{L}$ mounds, $\mathrm{M} / \mathrm{O}$ vs. $\mathrm{M} / \mathrm{M}$ mounds, and chemical vs. no-chemical site preparation.
Nous avons entrepris en 1984, à environ 200 km au nord de Sault Ste. Marie, en Ontario, des expériences sur le terrain pour évaluer le rendement du pin gris (Pinus banksiana Lamb.) (semis à racines nues $2+0$ et en godet-papier japonais $\mathrm{FH} 408$ ) en fonction de la préparation mécanique du terrain, dont le scarifiage au moyen d'un cultivateur Bracke avec ou sans aménagement de buttes et l'application de l'herbicide Roundup ${ }^{\circledR}$ avant plantation. Nous avons appliqué 20 traitements différents à 4480 arbres répartis dans des parcelles de 40 arbres; la moitié de ces parcelles renfermaient de semis à racines nues et l'autre, des semis en godet-papier. Le sol en cet endroit est un loam limoneux profond. Après 3 saisons de croissance, le taux de survie des semis à racines nues était supérieur à celui des semis en godet, mais les taux de survie des deux types de semis ne différaient plus de façon significative $(P<0,05) 2$ ans plus tard. Au cours des quatrième et cinquième années, le taux d'allongement moyen des semis à racines nues était de $11 \%$ inférieur à celui des semis en godet-papier, mais la hauteur totale et l'allongement moyens des semis à racines nues étaient respectivement de 40 et de $4,7 \mathrm{~cm}$ supérieurs dans la cinquième année. Les semis en godetpapier avaient davantage besoin que le terrain soit préparé mécaniquement. Vers la fin de la cinquième année, nous avons observé un effet positif évident des buttes sur la survie et la croissance des deux types de semis; la taille des buttes avait peu ou pas d'effet sur la survie et la hauteur des plants, mais le volume moyen des tiges sur les buttes de $20 \mathrm{~L}$ était significativement supérieur $(P<0,01)$ à celui des tiges des plants des buttes de $10 \mathrm{~L}$. Le volume moyen des tiges des semis sur buttes constituées de sol minéral sur sol organique était significativement supérieur $(P<0,01)$ à celui des tiges des plants des buttes constituées de sol minéral sur minéral sur sol minéral. L'utilisation d'herbicide n'a plus eu d'effet sur les taux de croissance relatifs audelà de la troisième année. Des indices combinant le taux de survie et la hauteur totale ou le volume de la tige après 5 ans ont montré de façon statistiquement significative $(P<0,01)$ que l'utilisation d'herbicide accroît le rendement et que les buttes de $20 \mathrm{~L}$ sont plus efficaces que les buttes de $10 \mathrm{~L}$, tout comme les buttes $\mathrm{M} / \mathrm{O}$ par rapport aux buttes $\mathrm{M} / \mathrm{M}$.

\section{Introduction}

Plantations of conifers in boreal regions are seldom successful without site preparation (Bärring 1965, 1967; Alm 1974; Söderström 1977; Söderström et al. 1978, 1979; Berg 1980; Martinsson 1985). Innumerable combinations of kinds, timings, and intensities of site preparation treatment are possible. Choosing a cost-efficient method of site preparation to secure the desired results from outplanting is one of the most difficult tasks facing the forest manager (Wood et al. 1988).

The opportunity to test mounding site preparation (Sutton 1993) for establishing jack pine ${ }^{1}$ arose when the Lands and Forests Division of the Algoma Central Railway (ACR)

Department of Natural Resources Canada, Canadian Forest Service, Ontario Region, Box 490, Sault Ste. Marie, Ontario, Canada P6A 5M7. initiated a planting program for land that, following pulpwood cutting (between 1925 and 1930) and fire, had become grassy and sparsely treed (Fig. 1). The site lies about $200 \mathrm{~km}$ north of Sault Ste. Marie, Ontario. In co-operation with W.L. Oliphant (then, Manager of ACR's Lands and Forests Division) and ACR's Forester S.W. Kent, field experimentation was designed and implemented. Three-year results were reported by Wood et al. (1988). The 5-year results presented here are examined similarly as well as by the method of contrasts between weighted means. Indications that contradict those suggested by the 3-year data are emphasized.

${ }^{1}$ Botanical names for species mentioned in the text are given in Appendix A. 




Figure 1. General view of the experimental site before planting.

\section{Objective}

The objective of the experimentation was to assess the field performance of bareroot and paperpot jack pine in relation to several site preparation and planting treatments, especially mounding.

\section{Experimental Design}

The experimental design allowed comparisons of performance between two stock types outplanted after 20 kinds of site treatments (Table 1, Fig. 2). Plots split by stock type, with 20 bareroot and 20 paperpot trees per plot, were used in a randomized block design. Eight of the 20 treatments were doubly replicated within each of the four blocks: each block of 28 plots contained two plots each of treatments 5, 6, $9,10,13,14,17$, and 18 , and one plot each of the other 12 treatments. Within blocks, treatments were randomly assigned. This gave either $20 \times 4=80$ or $2 \times 20 \times 4=$ 160 trees per stock type per treatment, for a total of 2240 trees per stock type.

\section{Site}

Located at a mean elevation of about $325 \mathrm{~m}$ near Eton $\left(47^{\circ} 30^{\prime} \mathrm{N}, 84^{\circ} 30^{\prime} \mathrm{W}\right)$ in Bullock Township in the Algoma Section (L.10) of the Great Lakes/St. Lawrence forest region (Rowe 1972), the study area had gently rolling topography on deep glaciofluvial deposits, with mainly silt loam soils. Scattered individual stems and small clumps of aspen, black spruce, and jack pine were present; grasses, blueberries, strawberry, and bracken were abundant.

\section{Treatments}

\section{Stock Type}

Superimposed on the 20 treatments was the comparison between spring-lifted $2+0$ bareroot stock and overwintered FH408 Japanese paperpot stock. The stock, planted in May 1984, was described in detail by Wood et al. (1988). The stock types tested in our study were in current operational use in Ontario.

\section{Bracke Scarification}

A skidder-mounted Bracke scarifier prepared the site in June 1983. In each of four experimental blocks, seven passes were made up one side and another seven passes down the other, each pass creating two rows of patches. Patch size, which has influenced performance in some studies (Bärring 1965; Söderström et al. 1978; Sloan and Ryker 1986), was not investigated in our study, in which Bracke patches were of average size, about $63 \times 80 \mathrm{~cm}$ (Smith 1979).

\begin{tabular}{|c|c|c|c|c|c|c|}
\hline \multirow{2}{*}{$\begin{array}{c}\text { Treatment } \\
\text { no. }\end{array}$} & \multirow[b]{2}{*}{ Bracke scarification } & \multirow[b]{2}{*}{ Mounding } & \multicolumn{3}{|c|}{ Mound } & \multirow[b]{2}{*}{ Herbicide $^{3}$} \\
\hline & & & shape $^{1}$ & position $^{2}$ & volume $(\mathrm{L})$ & \\
\hline 1 & - & - & $\mathrm{n} / \mathrm{a}$ & $\mathrm{n} / \mathrm{a}$ & $\mathrm{n} / \mathrm{a}$ & - \\
\hline 2 & - & - & $\mathrm{n} / \mathrm{a}$ & $\mathrm{n} / \mathrm{a}$ & $\mathrm{n} / \mathrm{a}$ & + \\
\hline 3 & + & - & $\mathrm{n} / \mathrm{a}$ & $\mathrm{n} / \mathrm{a}$ & $\mathrm{n} / \mathrm{a}$ & - \\
\hline 4 & + & - & $\mathrm{n} / \mathrm{a}$ & $\mathrm{n} / \mathrm{a}$ & $\mathrm{n} / \mathrm{a}$ & + \\
\hline 5 & + & + & $\mathrm{P}$ & $\mathrm{M} / \mathrm{M}$ & 10 & - \\
\hline 6 & + & + & $\mathrm{P}$ & $\mathrm{M} / \mathrm{M}$ & 10 & + \\
\hline 7 & + & + & $\mathrm{P}$ & $\mathrm{M} / \mathrm{M}$ & 20 & - \\
\hline 8 & + & + & P & $\mathrm{M} / \mathrm{M}$ & 20 & + \\
\hline 9 & + & + & $\mathrm{P}$ & $\mathrm{M} / \mathrm{O}$ & 10 & - \\
\hline 10 & + & + & P & $\mathrm{M} / \mathrm{O}$ & 10 & + \\
\hline 11 & + & + & $\mathrm{P}$ & $\mathrm{M} / \mathrm{O}$ & 20 & - \\
\hline 12 & + & + & $\mathrm{P}$ & $\mathrm{M} / \mathrm{O}$ & 20 & + \\
\hline 13 & + & + & D & $\mathrm{M} / \mathrm{M}$ & 10 & - \\
\hline 14 & + & + & $\mathrm{D}$ & $\mathrm{M} / \mathrm{M}$ & 10 & + \\
\hline 15 & + & + & D & $\mathrm{M} / \mathrm{M}$ & 20 & - \\
\hline 16 & + & + & D & $\mathrm{M} / \mathrm{M}$ & 20 & + \\
\hline 17 & + & + & D & $\mathrm{M} / \mathrm{O}$ & 10 & - \\
\hline 18 & + & + & D & $\mathrm{M} / \mathrm{O}$ & 10 & + \\
\hline 19 & + & + & D & $\mathrm{M} / \mathrm{O}$ & 20 & - \\
\hline 20 & + & + & $\mathrm{D}$ & $\mathrm{M} / \mathrm{O}$ & 20 & + \\
\hline
\end{tabular}

${ }^{1} \mathrm{P}=$ "pimple" mound, convex surface; $\mathrm{D}=$ "dimple" mound, concave surface.

${ }^{2} \mathrm{M} / \mathrm{M}=$ mineral mound placed on mineral soil on shoulder of the Bracke patch; $\mathrm{M} / \mathrm{O}=$ mineral mound placed on organic substrate.

${ }^{3}$ Herbicide patch-treatment applied August 1983 prior to planting May 1984. 


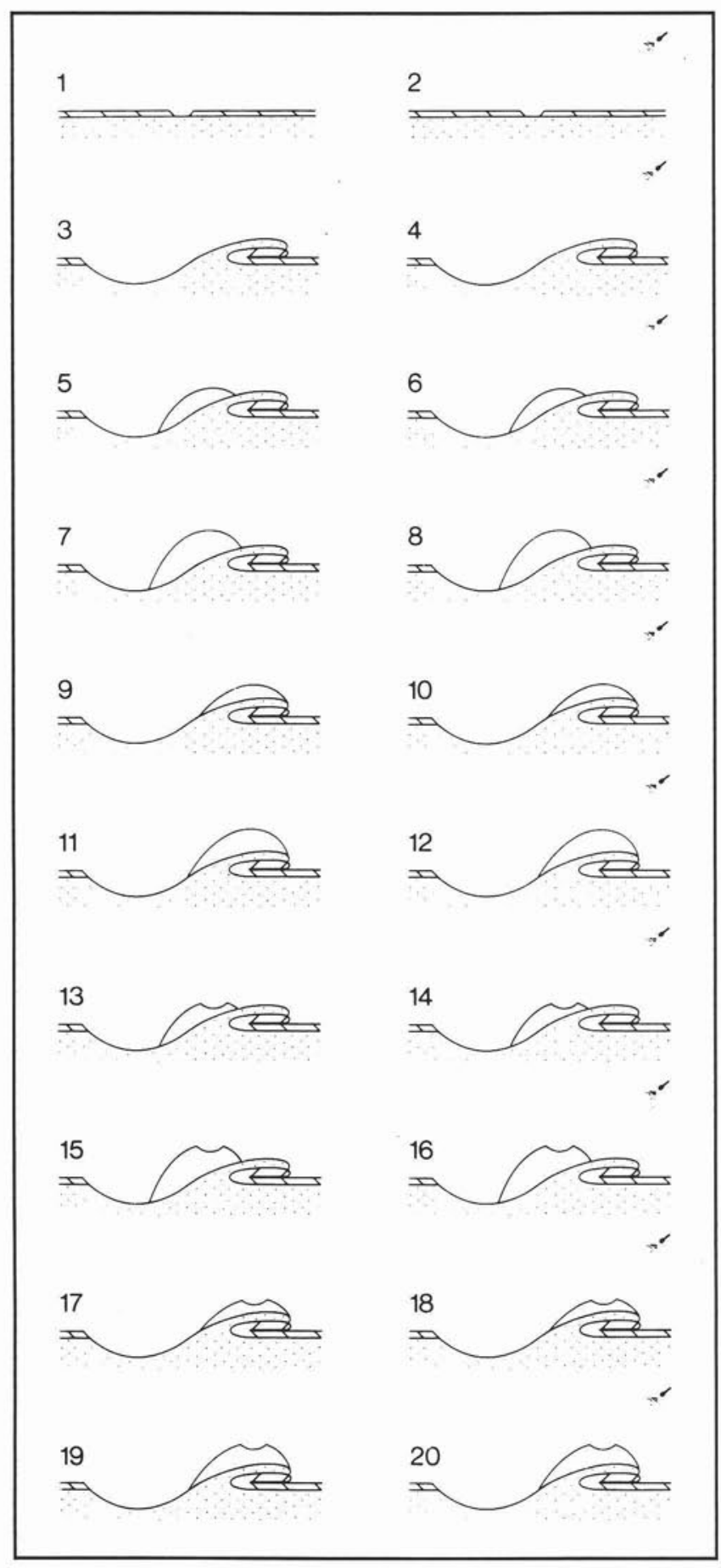

Figure 2. The treatments. denotes chemical spray.

\section{Mounding}

Mounds were made by hand in late June 1983 . The positioning of the mounds was sometimes difficult; with mounds of mineral soil on a substrate of mineral soil (M/M mounds), the shoulder was typically very steep, and with mounds of mineral soil on organic matter ( $\mathrm{M} / \mathrm{O}$ mounds), the organic divot from the patch had not always been deposited cleanly. "Dimple" mounds were formed in August 1983 by trampling to form a central concavity in the upper surface of the mounds. Other mounds were generally convex with a central high point; these constituted the "pimple" mounds.
Containers of known volume were used to obtain the required 10 or $20 \mathrm{~L}$ of mineral matter per mound.

\section{Chemical Site Preparation}

Backpack sprayers were used 30 and 31 August 1983 to apply Roundup ${ }^{\otimes}$ to a circular patch $1.4 \mathrm{~m}$ in diameter at $2.00 \mathrm{~kg}$ active ingredient/ha (5.6 L Roundup $\left.{ }^{\circledR} / \mathrm{ha}\right)$. The herbicide was mixed with water to make a $1.5 \%$ solution. Each tree in the herbicide treatments was to be planted centrally in a patch that had been treated, but the 30-day assessment revealed that, at least in the chemical site preparation treatment, only $56 \%$ of bareroot trees and $44 \%$ of paperpot had been planted in treated patches. Evaluation of this treatment must be weighted accordingly.

\section{Planting}

All stock was hand-planted into moist soil, paperpots on 13 and 14 May, bareroot on 14 and 15 May 1984. Plants were spaced about $2 \mathrm{~m}$ apart in rows about $2.5 \mathrm{~m}$ apart. The weather was partly sunny, cool in the morning and warmer in the afternoon, with light winds; there was frost by night. Weather data recorded at the experimental site from 11 June through 22 September 1984 indicated values close to the 30 -year norms for mean monthly minimum and mean monthly maximum temperatures at the federal weather station at Wawa, Ontario (Anon., undated), $430 \mathrm{~m}$ elevation, $48^{\circ} 04^{\prime} \mathrm{N}, 84^{\circ} 45^{\prime} \mathrm{W}$. Precipitation during this period was also close to normal.

\section{Data Collection}

Height and ground-level stem diameter of the newly planted stock were measured on 16 May 1984 . By that time, $10-20 \%$ of the paperpot stock and $60-70 \%$ of the bareroot stock already exhibited wilting (mostly temporary) of newly flushed foliage. Reassessments were carried out 30 days after planting and at the end of each of the 1st, 2nd, 3rd, and 5th growing seasons.

\section{Data Analysis}

The seedling performance parameters examined were survival, total height, height increment, stem diameter at ground level, stem volume, mean relative growth rates (RGR) for height and stem volume, Index I (mean tree height multiplied by percentage survival, 5-year data), and Index II (mean stem volume multiplied by percentage survival, 5-year data).

Relationships between the two indices were examined by regression analysis. Stem volume was calculated using the volume formula for a right-circular cone $(1 / 3$ basal area $X$ height). Relative growth rates were calculated using the formula given by Hunt (1982):

$$
\operatorname{RGR}\left(T_{2}-T_{1}\right)=\left(\log _{\mathrm{e}} W_{2}-\log _{\mathrm{e}} W_{1}\right) /\left(T_{2}-T_{1}\right)
$$

where $W_{2}$ and $W_{1}$ represent the parameter of interest (e.g., total height, stem volume, etc.) at time $2\left(T_{2}\right)$ and time 1 $\left(T_{1}\right)$, respectively. Mean RGR is expressed in units of time ${ }^{-1}$.

Five defined contrasts were also examined using weighted sums of means (Winer 1971): no site preparation vs. Bracke treatment only; no site preparation vs. chemical site preparation only; mounding site preparation vs. Bracke treatment 
only; $10-\mathrm{L}$ vs. $20-\mathrm{L}$ mounds; and $\mathrm{M} / \mathrm{M}$ vs. M/O mounds. Orthogonality is immaterial in such comparisons (Winer 1971; Milliken and Johnson 1984).

Survival data were analyzed by chi-square test (Steel and Torrie 1980). Growth data were analyzed using the P7D package (BMDP 1990) package for analysis of variance for balanced split-plot designs (Milliken and Johnson 1984). All expressions of significance are based on P 0.05 unless otherwise stated. Redundant analyses are not reported here, but all data are on file [TYPE 1423].

\section{Results}

After 5 growing seasons, the effects of treatments became clearer than were apparent to Wood et al. (1988) after 3 growing seasons. Comparisons of performance after 3 and 5 growing seasons were summarized for survival (Table 2), height (Table 3), stem volume (Table 4), and indices that combine survival and growth (Table 5). Regressions of Index II on Index I gave significant $(P<0.001) \mathrm{R}^{2}$ values of 0.798 and 0.871 for bareroot and paperpot stock, respectively. ANOVA for both indices gave virtually identical results for bareroot $\left(R^{2}=0.86\right)$ and paperpot $\left(R^{2}=0.88\right)$ stock; the effects of block, treatment, and stock type were all significant $(P<0.001)$, and neither the block $\times$ treatment nor the treatment $\times$ stock type interaction was significant. Significant relationships determined by analyses of the defined contrasts are listed (Table 6).

Differences in performance between the two stock types narrowed during the 4 th and 5 th growing seasons. In particular, the survival differential, significant in favor of bareroot stock after 3 growing seasons, became insignificant. Growth differentials decreased.

Mounding site preparation also became significantly superior to non-mounding scarification during the 4th and 5 th growing seasons. Mound size, which seemed to have little effect on survival or growth by the end of the 3rd growing season, had become significant after 5 growing seasons (Table 6). Mound type, which also "had little effect on survival or growth" up to the end of the 3rd growing season (Wood et al. 1988) showed significant (mostly $P<0.01$ ) effects in favor of M/O mounds (Table 6) when evaluated after 5 growing seasons using defined contrasts. For both stock types, both mound sizes, and both herbicide treatments, Index II values for stock planted on $\mathrm{M} / \mathrm{O}$ mounds exceeded those for stock planted on $\mathrm{M} / \mathrm{M}$ mounds; bareroot and paperpot stock planted on $\mathrm{M} / \mathrm{O}$ mounds averaged 115 and $129 \%$, respectively, of index values for trees planted on $\mathrm{M} / \mathrm{M}$ mounds (Table 5). Notwithstanding the imperfect locating of planting spots with respect to the chemically treated patches, chemical site preparation was found, after 3 growing seasons, to be giving growth responses "consistently in favor of chemical site preparation" (Wood et al. 1988); these indications were sustained after 5 growing seasons. Chemical site preparation had more effect with $\mathrm{M} / \mathrm{O}$ than with $\mathrm{M} / \mathrm{M}$ mounds and with paperpot than with bareroot stock.

\section{Discussion}

\section{Stock Type}

Stock types as disparate as bareroot and paperpot stock can be expected to perform differently after outplanting in a given environment. Martinsson (1985) found that the response to site preparation, including mounding, varied with stock type; classes and grades of stock within types may also respond very differently to site conditions (cf. Scarratt 1974; Dobbs 1976; McMinn 1982). Stock size also influences performance, and may be more important than stock type (cf. Ball and Kolabinski 1986). Of prime interest in the present study, therefore, are the temporal changes in the differential between the two stock types. Furthermore, since there can be great variation among lots of any given stock type (Sutton 1979; McCreary and Duryea 1985), extrapolation

Table 2. Survival of jack pine after three and five growing seasons, by treatment and stock type, showing the significance $(* *=P<0.01$, $*=P<0.05$, NS = not significant) of differences between bareroot and paperpot stock types

\begin{tabular}{|c|c|c|c|c|c|c|c|c|}
\hline \multirow{3}{*}{$\begin{array}{l}\text { Treatment } \\
\text { no. }\end{array}$} & \multicolumn{3}{|c|}{ Bareroot stock } & \multicolumn{3}{|c|}{ Paperpot stock } & \multirow{2}{*}{\multicolumn{2}{|c|}{$\begin{array}{c}\text { Difference between } \\
\text { bareroot and paperpot } \\
\text { survival at end of } \\
\end{array}$}} \\
\hline & \multirow{2}{*}{$\begin{array}{c}\text { 3rd yr } \\
(\%)\end{array}$} & \multirow{2}{*}{$\begin{array}{l}\text { 5th } \mathrm{yr} \\
(\%)\end{array}$} & \multirow{2}{*}{$\begin{array}{c}\text { Ratio } \\
\text { 5th-:3rd-yr } \\
\text { survival }\end{array}$} & \multirow{2}{*}{$\begin{array}{c}\text { 3rd yr } \\
(\%)\end{array}$} & \multirow{2}{*}{$\begin{array}{c}\text { 5th } \mathrm{yr} \\
(\%)\end{array}$} & \multirow{2}{*}{$\begin{array}{c}\text { Ratio } \\
\text { 5th-: 3rd-yr } \\
\text { survival }\end{array}$} & & \\
\hline & & & & & & & 3rd yr & 5th $\mathrm{yr}$ \\
\hline 1 & 75 & 60 & 0.80 & 36 & 31 & 0.86 & $* *$ & $* *$ \\
\hline 2 & 66 & 44 & 0.67 & 30 & 29 & 0.97 & $* *$ & * \\
\hline 3 & 88 & 62 & 0.70 & 80 & 58 & 0.72 & NS & NS \\
\hline 4 & 94 & 64 & 0.68 & 93 & 76 & 0.82 & NS & NS \\
\hline 5 & 98 & 84 & 0.86 & 81 & 76 & 0.94 & $* *$ & NS \\
\hline 6 & 94 & 74 & 0.79 & 91 & 74 & 0.81 & NS & NS \\
\hline 7 & 88 & 71 & 0.81 & 94 & 86 & 0.91 & NS & $* *$ \\
\hline 8 & 89 & 78 & 0.88 & 87 & 71 & 0.82 & NS & NS \\
\hline 9 & 94 & 81 & 0.86 & 85 & 80 & 0.94 & $* *$ & NS \\
\hline 10 & 92 & 81 & 0.88 & 83 & 78 & 0.94 & * & NS \\
\hline 11 & 91 & 78 & 0.86 & 91 & 87 & 0.96 & NS & $*$ \\
\hline 12 & 95 & 83 & 0.87 & 90 & 86 & 0.96 & NS & NS \\
\hline 13 & 95 & 74 & 0.78 & 93 & 70 & 0.75 & NS & NS \\
\hline 14 & 88 & 76 & 0.86 & 88 & 72 & 0.82 & NS & NS \\
\hline 15 & 98 & 85 & 0.87 & 85 & 79 & 0.93 & $* *$ & NS \\
\hline 16 & 94 & 82 & 0.87 & 95 & 85 & 0.89 & NS & NS \\
\hline 17 & 90 & 79 & 0.88 & 79 & 68 & 0.86 & $*$ & NS \\
\hline 18 & 89 & 79 & 0.89 & 93 & 88 & 0.95 & NS & NS \\
\hline 19 & 91 & 76 & 0.84 & 94 & 88 & 0.94 & NS & NS \\
\hline 20 & 89 & 72 & 0.81 & 86 & 78 & 0.91 & NS & NS \\
\hline Mean & 90 & 74 & 0.82 & 83 & 73 & 0.88 & $* *$ & NS \\
\hline
\end{tabular}


Table 3. Total height of jack pine after three and five growing seasons, by treatment and stock type. For each stock type, differences between treatment means of 6.7 (3rd-year) and $13.4 \mathrm{~cm}$ (5th-year) are significant $(P<0.05)$.

\begin{tabular}{|c|c|c|c|c|c|c|}
\hline \multirow[b]{2}{*}{$\begin{array}{c}\text { Treatment } \\
\text { no. }\end{array}$} & \multicolumn{3}{|c|}{ Bareroot stock } & \multicolumn{3}{|c|}{ Paperpot stock } \\
\hline & 3rd yr (cm) & 5th $\mathrm{yr}(\mathrm{cm})$ & $\begin{array}{c}\text { Ratio } \\
\text { 5th-:3rd-yr height }\end{array}$ & 3rd yr $(\mathrm{cm})$ & 5 th yr $(\mathrm{cm})$ & $\begin{array}{c}\text { Ratio } \\
\text { 5th-:3rd-yr heigh }\end{array}$ \\
\hline 1 & 82 & 176 & 2.15 & 55 & 126 & 2.29 \\
\hline 2 & 76 & 169 & 2.22 & 45 & 113 & 2.51 \\
\hline 3 & 81 & 156 & 1.93 & 53 & 114 & 2.15 \\
\hline 4 & 83 & 166 & 2.00 & 58 & 126 & 2.17 \\
\hline 5 & 95 & 182 & 1.92 & 62 & 143 & 2.31 \\
\hline 6 & 83 & 174 & 2.10 & 62 & 143 & 2.31 \\
\hline 7 & 93 & 193 & 2.08 & 64 & 150 & 2.34 \\
\hline 8 & 89 & 182 & 2.04 & 62 & 143 & 2.31 \\
\hline 9 & 100 & 196 & 1.96 & 66 & 151 & 2.29 \\
\hline 10 & 100 & 201 & 2.01 & 71 & 163 & 2.30 \\
\hline 11 & 91 & 192 & 2.11 & 65 & 149 & 2.29 \\
\hline 12 & 102 & 202 & 1.98 & 73 & 167 & 2.29 \\
\hline 13 & 93 & 196 & 2.11 & 63 & 145 & 2.30 \\
\hline 14 & 99 & 187 & 1.89 & 65 & 144 & 2.22 \\
\hline 15 & 95 & 181 & 1.91 & 71 & 150 & 2.11 \\
\hline 16 & 99 & 199 & 2.01 & 70 & 159 & 2.27 \\
\hline 17 & 96 & 196 & 2.04 & 68 & 144 & 2.12 \\
\hline 18 & 103 & 211 & 2.05 & 75 & 165 & 2.20 \\
\hline 19 & 94 & 186 & 1.98 & 70 & 160 & 2.29 \\
\hline 20 & 94 & 206 & 2.19 & 72 & 161 & 2.24 \\
\hline Mean & 92 & 188 & 2.03 & 64 & 146 & 2.27 \\
\hline
\end{tabular}

Table 4. Computed stem volume of jack pine after three and five growing seasons, by treatment and stock type. For each stock type, differences between treatment means of 20.1 (3rd-year) and $171.0 \mathrm{~cm}^{3}$ (5th-year) are significant $(P<0.05)$.

\begin{tabular}{|c|c|c|c|c|c|c|}
\hline \multirow[b]{2}{*}{$\begin{array}{c}\text { Treatment } \\
\text { no. }\end{array}$} & \multicolumn{3}{|c|}{ Bareroot stock } & \multicolumn{3}{|c|}{ Paperpot stock } \\
\hline & 3rd $\mathrm{yr}\left(\mathrm{cm}^{3}\right)$ & 5th $\mathrm{yr}\left(\mathrm{cm}^{3}\right)$ & $\begin{array}{c}\text { Ratio } \\
\text { 5th-:3rd-yr volume }\end{array}$ & 3rd yr $\left(\mathrm{cm}^{3}\right)$ & 5th $\mathrm{yr}\left(\mathrm{cm}^{3}\right)$ & $\begin{array}{c}\text { Ratio } \\
\text { 5th-:3rd-yr volume }\end{array}$ \\
\hline 1 & 53 & 495 & 9.34 & 14 & 181 & 12.93 \\
\hline 2 & 40 & 458 & 11.45 & 14 & 211 & 15.07 \\
\hline 3 & 56 & 410 & 7.32 & 17 & 190 & 11.18 \\
\hline 4 & 68 & 569 & 8.37 & 24 & 221 & 9.21 \\
\hline 5 & 93 & 738 & 7.94 & 27 & 346 & 12.81 \\
\hline 6 & 80 & 700 & 8.75 & 30 & 378 & 12.60 \\
\hline 7 & 103 & 881 & 8.55 & 29 & 426 & 14.69 \\
\hline 8 & 84 & 652 & 7.76 & 36 & 422 & 11.72 \\
\hline 9 & 110 & 860 & 7.82 & 33 & 460 & 13.94 \\
\hline 10 & 115 & 1021 & 8.88 & 47 & 562 & 11.96 \\
\hline 11 & 92 & 859 & 9.34 & 32 & 425 & 13.28 \\
\hline 12 & 137 & 1002 & 7.31 & 51 & 588 & 11.53 \\
\hline 13 & 86 & 806 & 9.37 & 23 & 289 & 12.57 \\
\hline 14 & 105 & 759 & 7.23 & 33 & 404 & 12.24 \\
\hline 15 & 86 & 652 & 7.58 & 38 & 386 & 10.16 \\
\hline 16 & 136 & 1139 & 8.38 & 42 & 488 & 11.62 \\
\hline 17 & 75 & 653 & 8.71 & 31 & 339 & 10.94 \\
\hline 18 & 126 & 920 & 7.30 & 41 & 454 & 11.07 \\
\hline 19 & 97 & 756 & 7.79 & 37 & 439 & 11.86 \\
\hline 20 & 122 & 1142 & 9.36 & 50 & 572 & 11.44 \\
\hline Mean & 93 & 774 & 8.30 & $32^{1}$ & $389^{1}$ & 12.01 \\
\hline
\end{tabular}

${ }^{1}$ Significantly $(P<0.0001)$ different from the equivalent bareroot stock mean.

of the results of any study that uses but one stock lot per type must be done with caution.

(a) Survival. Mortality was higher among bareroot than paperpot stock during the 4th and 5th growing seasons, eliminating the significant $(P<0.01)$ overall 3 rd-year differences between stock types reported by Wood et al. (1988) (Table 2). Survival rates in five of the seven treatments that showed significant (mostly $P<0.01$ ) differences in favor of bareroot stock after 3 growing seasons were no longer significant after 5 growing seasons. Bareroot survival rates in the two treatments without mechanical site preparation also lost ground compared with paperpot survival but remained significantly $(P<0.01$ in treatment 1) higher than paperpot survival rates. Thus, site preparation involving cultivation was more necessary for the relatively small containerized stock than for the bareroot stock. Moreover, in treatments 7 and 11 (20-L M/M and M/O mounds, respectively, without chemical site preparation), paperpot survival during the 4 th and 5 th growing 
Table 5. Index I and Index II (see texte) for jack pine, by treatment and stock type. For each stock type, differences between treatment means of 23.8 (Index I) and 177.5 (Index II are significant $(P<0.05$ )

\begin{tabular}{cccccc}
\hline & \multicolumn{2}{c}{ Bareroot stock } & & \multicolumn{2}{c}{ Paperpot stock } \\
\cline { 2 - 3 } \cline { 5 - 6 } Treatment & Index I & Index II & & Index I & Index II \\
\hline 1 & 106 & 297 & 39 & 56 \\
2 & 74 & 200 & & 32 & 61 \\
3 & 98 & 256 & 65 & 109 \\
4 & 106 & 363 & & 97 & 172 \\
5 & 154 & 622 & & 109 & 263 \\
6 & 128 & 516 & 107 & 281 \\
7 & 137 & 627 & 129 & 368 \\
8 & 141 & 505 & 101 & 298 \\
9 & 158 & 693 & 122 & 370 \\
10 & 162 & 823 & 126 & 432 \\
11 & 149 & 665 & 130 & 369 \\
12 & 168 & 833 & & 143 & 503 \\
13 & 142 & 584 & 103 & 206 \\
14 & 142 & 579 & 105 & 293 \\
15 & 154 & 554 & 118 & 303 \\
16 & 164 & 940 & & 135 & 414 \\
17 & 154 & 514 & 97 & 229 \\
18 & 164 & 713 & 144 & 397 \\
19 & 142 & 576 & 140 & 384 \\
20 & 149 & 828 & 125 & 443 \\
\hline
\end{tabular}

Table 6. Variables found to be significant $\left(^{*}=P<0.05\right.$, ** $=$ $P<0.01)$ using defined contrasts

\begin{tabular}{|c|c|}
\hline Contrast $^{1}$ & Variables \\
\hline $\begin{array}{l}\text { no site preparation vs. } \\
\text { Bracke only }\end{array}$ & $\begin{array}{l}\text { Total height } * * \text { and height increment } 1988^{* *} \\
\text { RGR (volume** and height**, years } 4-5 \text { ). }\end{array}$ \\
\hline $\begin{array}{l}\text { no site preparation vs. } \\
\text { chemical site prep }\end{array}$ & $\begin{array}{l}\text { Total height } 1984^{*} \text { and } 1985^{* *} \text {, and height } \\
\text { increment } 1985^{*} \text {. }\end{array}$ \\
\hline $\begin{array}{l}\text { mounding vs. } \\
\text { Bracke }\end{array}$ & $\begin{array}{l}\text { Ground-level stem diameter } 1984^{*}, 1985^{* *} \text {, } \\
1986^{* *} \text {, and 1988**; total height } 1985^{* *} \text {, } \\
1986^{* *} \text {; and } 1988^{* *} \text {; height increment } 1985^{*} \text {, } \\
1986^{* *} \text {, and } 1988^{* *} \text {; stem volume } 1986^{* *} \text { and } \\
1988^{* *} \text {; and RGR (volume** years } 0-3,0-5 \text {, and } \\
4-5 \text { ) and RGR (height** years } 0-3,0.5 \text {, and 4-5). }\end{array}$ \\
\hline $\begin{array}{l}10-\mathrm{L} \text { mounds vs. } \\
20-\mathrm{L} \text { mounds }\end{array}$ & $\begin{array}{l}\text { Ground-level stem diameter } 1986^{* *} \text { and } 1988^{* *} \text {; } \\
\text { stem volume } 1986^{* *} \text { and } 1988^{* *} \text {; and RGR } \\
\text { (volume** years } 0-3 \text { and } 0-5 \text { ). }\end{array}$ \\
\hline $\begin{array}{l}\mathrm{M} / \mathrm{M} \text { mounds vs. } \\
\mathrm{M} / \mathrm{O} \text { mounds }\end{array}$ & $\begin{array}{l}\text { Ground-level stem diameter } 1984^{*}, 1985^{* *} \text {, } \\
1986^{* *} \text {, and } 1988^{* *} \text {; total height } 1985^{*} \text {, } \\
1986^{* *} \text {, and } 1988^{* *} \text {; height increment } 1985^{* *} \text {, } \\
1986^{* *} \text {, and } 1988^{* *} \text {; stem volume } 1986^{* *} \text { and } \\
1988^{* *} \text {; and RGR (volume** years } 0-3 \text { and } 0-5 \text { ), } \\
\text { and RGR (height** years } 0-3 \text { and } 0-5 \text { ). }\end{array}$ \\
\hline
\end{tabular}

${ }^{1}$ In each contrast, the boldfaced member identifies the treatment associated with significantly superior performances with respect to the specified variables.

seasons became significantly higher than bareroot survival (Table 2).

(b) Growth. Differentials in height and volume between the two stock types decreased markedly during the 4 th and 5 th growing seasons. After 5 growing seasons, paperpot stock was closer in total height and volume to 5th- than to 3rd-year values attained by bareroot stock (Tables 3 and 4). These developments were reflected well by the appropriate RGRs; for instance, the overall RGR (volume) of paperpot stock exceeded that of bareroot stock by $5 \%$ after 3 growing seasons, $9 \%$ after 5 , and $22 \%$ during the 4 th and 5 th growing seasons (data on file). On both mound types, the RGRs (volume) of paperpot stock were significantly greater than those of bareroot stock. Paperpot growth performance was catching up with that of bareroot stock.

\section{Scarification}

(a) Survival. In both stock types, the superiority of scarification without mounding compared with no scarification decreased in the 4th and 5th growing seasons. The differentials decreased from $20 \%$ to $11 \%$ for bareroot and from $53 \%$ to $37 \%$ for paperpot stock. Elsewhere, Söderström (1977), Söderström et al. (1979), Berg (1980), and Martinsson (1985) found that mechanical site preparation typically increased survival rates compared with survival on untreated sites.

Compared with mounding, Bracke scarification without mounding gave lower 5th-year survival of paperpot stock in five of the eight mounding treatments, though there had been no difference 2 years earlier. Among bareroot stock as well, the differential in survival increased in favor of the mounded treatments by the end of the 5 th growing season in relation to that in the scarified-only treatment.

(b) Growth. Fifth-year total heights of both bareroot and paperpot stock without chemical site preparation were significantly greater in the untreated control than in the Brackeonly treatment. This was unexpected, for the presence or absence of Bracke patch had not significantly influenced 3rdyear total height for both stock types combined. With chemical site preparation, paperpot stock in the Bracke patch treatment were significantly taller after 5 growing seasons than were those with no Bracke patches; but bareroot stock showed no such response.

Bracke patch site preparation without mounding gave a 5thyear mean stem volume not significantly different from that reported by Sutton (1991) for jack pine treated similarly in another boreal Ontario study.

Compared with Bracke scarification by itself, mounding gave significantly $(P<0.01)$ higher RGR (volume) for years 4 through 5 as well as for years 0 through 5 (Table 6).

In other studies on cutover sites, 3-year results with jack pine (Sutton 1984), 5-year results with jack pine and black spruce (Sutton 1991), and 6-year results with Scots pine, lodgepole pine, and Norway spruce (Martinsson 1985), have shown that mounding is commonly less or no more effective than patch scarification.

\section{Mounding}

(a) Survival. Mounding, though it had not improved 3rdyear survival of bareroot stock, clearly became superior to patch scarification without mounding by the end of the 5th growing season. Among paperpot stock on mounds without chemical site preparation, 5th-year survival in all eight treatments was higher than with Bracke scarification alone.

In another study in boreal Ontario, survival rates in 11 outplantings averaged $92 \%$ after 5 growing seasons for $2+0$ jack pine planted after Bracke patch scarification, with or without mounding (Sutton 1991); after 3 growing seasons, mortality had been $4 \%$ higher among mound-planted stock than for patch scarification without mounding, but whereas mortality continued to increase in the non-mounded treatments, there was no further mortality in the mounded treatments. In a Swedish study, Martinsson (1985) found 1st-year through 6th-year survival rates to be virtually identical among $2+0$ Scots pine whether planting had been on mounds or in scarified patches. 
(b) Growth. Mounding increased total height in both stock types. Mean 5th-year total heights for paperpot stock were lower in all four, and for bareroot stock lower in three of the four, non-mounding treatments than in any of the 16 mounding treatments. In another boreal Ontario study with 11 outplantings of $2+0$ bareroot jack pine, Sutton (1991) reported 5-year data showing, at least with respect to bareroot stock, that mounding site preparation conferred no benefit compared with regular Bracke scarification. In Sweden, Martinsson (1985) obtained superior 3rd-year total height in $1+0$ Kopparfors containerized Scots pine planted in scarified patches compared with those planted in mounds. For lodgepole pine, a similar effect was even stronger. In contrast, the Eton site in the present study seems to be conducive to obtaining height responses to mounding, perhaps because of its greater grassiness compared with typical cutovers.

In the study on 11 sites in boreal Ontario, Sutton (1991) found that 3rd-year mean computed stem volume of $2+0$ jack pine averaged $49 \mathrm{~cm}^{3}$ in jack pine outplanted on the shoulder of the Bracke patch, $35 \mathrm{~cm}^{3}$ in those planted in the bottom of the patch, $55 \mathrm{~cm}^{3}$ on the $\mathrm{M} / \mathrm{M}$ mounds, and $54 \mathrm{~cm}^{3}$ on the $\mathrm{M} / \mathrm{O}$ mounds. Fifth-year values of 438,337 , 493 , and $465 \mathrm{~cm}^{3}$, respectively, represented increases of $895,955,895$, and $859 \%$, respectively, between the 3rd and 5 th years. However, rankings varied with site, and the Bracke patch shoulder and each kind of mound gave the best results on at least two of the sites. The response attributable to mounding was much greater on the grassy site of the Eton study reported here than on Sutton's (1991) 11 cutover sites.

In the present study, although mound size was found by analysis of variance to have a non-significant effect on 3rdyear (Wood et al. 1988) and 5th-year total heights and stem volumes, the method of defined contrasts showed that the mean stem volumes of trees of each stock type planted on 20 -L mounds were significantly $(P<0.01)$ greater than those of trees on the 10-L mounds both at the end of 3 years and after 5 growing seasons (Table 6). Differentials in Index II values in favor of 20 - $\mathrm{L}$ mounds averaged 110 and $127 \%$ for bareroot and paperpot stock, respectively (data of file).

Similarly, M/O mounds gave significantly $(P<0.01)$ greater 3rd-year and 5th-yar stem volumes than did M/M mounds (Table 6). Paperpot stock responded more strongly than did bareroot stock. With chemical site preparation, trees on $\mathrm{M} / \mathrm{O}$ mounds were significantly taller after 5 growing seasons than were trees on $\mathrm{M} / \mathrm{M}$ mounds in all four comparisons (data on file). Without chemical site preparation, mound type had no significant effect on mean stem volume; with chemical site preparation, most differences, and all significant differences, were in favor of the $\mathrm{M} / \mathrm{O}$ mounds (data on file). All eight comparisons of Index II values between mound types were in favor of stock planted on $\mathrm{M} / \mathrm{O}$ mounds, with average differentials of 115 and $129 \%$ for bareroot and paperpot stock, respectively (data on file).

Earlier indications by Wood et al. (1988) of higher RGR among stock on $\mathrm{M} / \mathrm{O}$ mounds than on $\mathrm{M} / \mathrm{M}$ mounds, though confirmed by significant $(P<0.01)$ differences in RGR (years 0 through 5 ) when examined by defined contrasts, were not maintained in years 4 through 5 . By analysis of variance, neither mound type nor chemical site preparation influenced RGR (volume) of bareroot stock significantly, whether for years 0 through 5 or for years 4 through 5 (data on file). For paperpot stock, RGR for years 4 and 5 showed a similar lack of influence by mound type and chemical site preparation, but the significantly $(P<0.01)$ higher RGR (years 0 through 5) of stock on the $\mathrm{M} / \mathrm{O}$ mounds in the chemical site preparation treatment than in the other treatments follows the initial positive response to chemical site preparation noted by Wood et al. (1988). Evaluation using defined contrasts also showed that, through the first 5 years after outplanting, paperpot stock on $\mathrm{M} / \mathrm{O}$ mounds with chemical site preparation achieved RGRs significantly higher than for any other treatment combination.

\section{Chemical Site Preparation}

(a) Survival. Chemical site preparation had no effect on 5th-year survival of either bareroot or paperpot stock, perhaps reflecting the compromised effectiveness of the chemical treatment already noted.

(b) Growth. Seven of the eight Index II comparisons favored chemical site preparation, with differentials of 118 and $123 \%$ for bareroot and paperpot stock, respectively (data on file). For trees on $\mathrm{M} / \mathrm{O}$ mounds, there are indications of a positive response of total height to chemical site preparation.

\section{Summary and Conclusions}

\section{Stock Type}

Acceptable survival depended on mechanical site preparation, especially for paperpot stock. Over all, mortality during the 4 th and 5 th growing seasons was $54 \%$ greater among bareroot than among paperpot stock; by the end of the 5th growing season, the two stock types no longer differed significantly in survival.

On mounds, both stock types performed satisfactorily.

Given sufficient site preparation, performance of paperpot stock after 5 growing seasons was as good or better than that of bareroot stock after 4 growing seasons, although the relative long-term stability of the two stock types must still be determined.

\section{Mechanical Site Preparation}

Mechanical site preparation by Bracke scarification without mounding gave significantly lower 5-year total height, stem volume, and relative growth rates than did Bracke scarification with mounding. The grassiness of our Eton site may have been a factor in determining the response to mounding.

The superiority of $\mathrm{M} / \mathrm{O}$ mounding compared with $\mathrm{M} / \mathrm{M}$ mounding became obvious during the 4 th and 5 th years, especially in paperpot stock. Most differences between mound types were significant.

Mound size made no difference to survival rates of bareroot stock, but paperpot stock survival averaged $10 \%$ more on 20 -L than on $10-\mathrm{L}$ mounds. Stem volume was significantly $(P<0.01)$ greater on 20 -L than on $10-\mathrm{L}$ mounds.

On these grassy sites, mounding gave responses in jack pine that were generally strong, consistent, and positive.

\section{Chemical Site Preparation}

Early indications that chemical site preparation was giving positive growth responses (cf. Wood et al. 1988) were maintained through the 5th growing season, particularly on $\mathrm{M} / \mathrm{O}$ mounds.

\section{Acknowledgments}

The authors thank Messrs. W.L. Oliphant, S.W. Kent, and G. Raines, all of the Algoma Central Railway's Lands and 
Forest Division, who provided field support to establish the study and monitor performance. In addition, we acknowledge the contributions made by two programs sponsored by the Government of Canada: Unemployment Insurance Job Creation - Forestry Sector; and Environment 2000.

\section{References}

Alm, A.A. 1974. Pine tubeling survival varies with vegetative competition. USDA For. Serv., Tree Planters' Notes 25: 33-36.

Anon., undated. Canadian climate normals 1951-1980: temperature and precipitation, Ontario. Environ. Can., Atmospher. Environ. Serv., 254 p.

Ball, W.J. and V.S. Kolabinski. 1986. Performance of container and bareroot stock on prescribed burns in Saskatchewan. Gov't of Can., Can. For. Serv., Edmonton, Alta., Inf. Rep. NOR-X-283, $16 \mathrm{p}$.

Bärring, U. 1965. On the importance of scalping and some other problems connected with planting of Pinus silvestris [sic] L. and Picea abies Karst. Stud. For. Suec. 24: 66 p. + summary and appendices.

Bärring, U. 1967. Studier av metoder för plantering av gran och tall pả ảkermark i södra och mellersta Sverige. Stud. For. Suec. 50: $1-332$.

Berg, S. 1980. Studies on the relationship between output and work quality in mechanized site preparation. pp. 169-201 In Symposium on Stand Establishment Techniques and Technology, Proc. IUFRO Subject Group S 3.02-00, Moscow.

BMDP 1990. BMDP Statistical software, 1990 version. BMDP Inc., Los Angeles, California.

Dobbs, R.C. 1976. Effect of initial mass of white spruce and lodgepole pine planting stock on field performance in the British Columbia interior. Dep. Environ., Can. For. Serv., Victoria, B.C. Rep. BC$\mathrm{X}-149,14 \mathrm{p}$.

Fernald, M.L. 1950. Gray's manual of botany, 8th ed. Am. Book, New York, 1632 p.

Hosie, R.C. 1969. Native trees of Canada, 7th ed. Dep. Fish. For., Can. For. Serv., Ottawa, Ont., 380 p.

Hunt, R. 1982. Plant growth curves: the functional approach to plant growth analysis. Arnold, London, $248 \mathrm{p}$.

Martinsson, O. 1985. Markberedningens inflytande pả överlevnad, tillväxt och rot/skott-relation i föryngringar av tall, gran och contorta. Sver. Lantbr. Inst. f. Skogs., Umeả, Sweden, Rep. No. 15, 29 p.

McCreary, D.D. and M.L. Duryea. 1985. OSU vigor test: principles, procedures, and predictive ability. pp. 85-92 In M.L. Duryea, Ed. Evaluating seedling quality: principles, procedures, and predictive abilities or major tests. Oregon State Univ., For. Res. Lab., Corvallis, Oregon.

McMinn, R.G. 1982. Size of container-grown seedlings should be matched to site conditions. pp. 307-312 In J.B. Scarratt, C. Glerum and C.A. Plexman, Eds. Proc. Canadian containerized tree seedling symposium. Dep. Environ., Can. For. Serv., Sault Ste. Marie, Ont., OFRC Symp. Proc. O-P-10.

Milliken, G.A. and D.E. Johnson. 1984. Analysis of messy data. Vol. 1: Designed experiments. Van Nostrand Reinhold, New York, $473 \mathrm{p}$.

Rowe, J.S. 1972. Forest regions of Canada. Dep. Environ., Can. For. Serv., Ottawa, Ont., Publ. 1300, 172 p.

Scarratt, J.B. 1974. Performance of tubed seedlings in Ontario. pp. 310-320 In R.W. Tinus, W.I. Stein and W.E. Balmer, Eds. Proc. North American containerized tree seedling symposium. Great Plains Agric. Counc. Publ. No. 68.

Sloan, J.P. and R.A. Ryker. 1986. Large scalps improve survival and growth of planted conifers in central Idaho. USDA For. Serv., Intermountain For. Res. Sta., Ogden, Utah, Res. Rep. INT-366. 9 p.

Smith, C.R. 1979. Bracke cultivator scarifier/seeder. Leaflet F1
In C.R. Smith (Comp.), Silvicultural equipment reference catalogue for northern Ontario. Ont. Min. Nat. Resour., For. Resour. Br., Toronto, Ont.

Söderström, V. 1977. Problem och metoder i skogsföryngringsarbetet. IV Försök med markberedningsmetoder. K. Skogs-o. Lantbr. Akad. Tidskr. 116: 43-58.

Söderström, V., J. Backe, R. Byfalk and C. Jonsson. 1978. Jämförelse mellan plantering $\mathrm{i}$ jordrabatter och efter andra markberedningsmetoder. Skogshögskolan, Inst. f. Skogs., Umeả, Sweden, Rapp. och uppsatser No. 11, 177 p.

Söderström, V., C. Jonsson and R. Byfalk, 1979. Optimal fläckstorlek vid markberedning för planteringett principförsök. Sver. Lantbr., Inst. f. Skogs., Umeả, Sweden, Intern. Rep. 1979-2. 13 p. Soper, J.H. and M.L. Heimburger. 1982. Shrubs of Ontario. Roy. Ont. Museum, Toronto, Ont. 495 p.

Steel, R.G.D. and J.H. Torrie. 1980. Principles and procedures of statistics: a biometrical approach, 2nd ed. McGraw-Hill, New York. 633 p.

Sutton, R.F. 1979. Planting stock quality and grading. For. Ecol. Manage. 2: 123-132.

Sutton, R.F. 1984. Mounding site preparation: evaluation of jack pine outplantings in a boreal Ontario study. pp. 66-77 In C.R. Smith and G. Brown (Cochairmen), Jack pine symposium proceedings. Dep. Environ., Can. For. Serv., Sault Ste. Marie, Ont., COJFRC Symp. Proc. O-P-12.

Sutton, R.F. 1991. Mounding site preparation for jack pine and black spruce in boreal Ontario: five-year results. For. Can., Ont. Region, Sault Ste. Marie, Ont., COFRDA Rep. 3311, 24 p. Sutton, R.F. 1993. Mounding site preparation: a review of European and North American experience. New For. 7: 151-192.

Winer, B.J. 1971. Statistical principles in experimental design, 2nd ed. McGraw-Hill, New York, 907 p.

Wood, J.E., R.F. Sutton, T.P. Weldon and H. Rissanen. 1988. Jack pine establishment: effect of stock type, Bräcke scarification, mounding, and chemical site preparation. Three-year results. Gov't of Can., Can. For. Serv., Sault Ste. Marie, Ont. Inf. Rep. O-X-393, $16 \mathrm{p}$.

\section{Appendix A}

Botanical names and authorities ${ }^{2}$ for: (a) tree species mentioned in the text, and (b) the lesser flora at Eton (A = abundant, $\mathrm{C}=$ common, and $\mathrm{P}=$ present).

(a) black spruce (Picea mariana [Mill.] B.S.P.)

jack pine (Pinus banksiana Lamb.)

lodgepole pine ( $P$. contorta Dougl.)

Norway spruce (Picea abies [L.] Karst.)

Scots pine ( $P$. sylvestris L.)

trembling aspen (Populus tremuloides Michx.)

(b) pincherry (Prunus pensylvanica L. fil) $\mathrm{P}$ chokecherry $(P$. virginiana $\mathrm{L}$. fil) $\mathrm{P}$

mountain alder (Alnus crispa [Ait.] Pursh) C juneberry (Amelanchier bartramiana [Tausch] Roem.) C blueberries (Vaccinium myrtilloides Michx.,

V. angustifolium Ait.) A

Labrador tea (Ledum groenlandicum Oeder) $\mathrm{P}$

currant (Ribes L. spp.) P

bramble (Rubus L. spp.) P

fireweed (Epilobium L. sp.) P

strawberry (Fragaria virginiana Duchesne) A

bracken (Pteridium aquilinum [L.] Kuhn) A

goldenrods (Solidago L. spp.) C

${ }^{2}$ Trees after Hosie (1969), shrubs according to Soper and Heimburger (1982), and other plants according to Fernald (1950). 
pearly everlasting (Anaphalis margaritacea [L.]

C.B. Clarke) $\mathrm{P}$

kidney-leaved violet (Viola renifolia Gray) C

bunchberry (Cornus canadensis L.) C

closed gentian (Gentian andrewsii Griseb.) P

spreading dogbane (Apocynum androsaemifolium L.) P

rose (Rosa L. spp.) P hair-cap moss (Polytrichum Dill. sp.) C plume moss (Hypnum crista-castrensis Hedw.) C common hairgrass (Deschampsia flexuosa [L.] Trin.) C fringed brome grass (Bromus ciliatus L.) C poverty grass (Danthonia spicata $[L$.$] Beauv.) C$ winter grass (Oryzopsis asperfolia Michx.) C

\section{Membership Dues 1993-1994}

\section{Active Membership}

1 st and 2nd year after graduation

(grad 1992, grad 1991) *(\$2.49 G.S.T. inc.)

Other new members for first year * $\$ 2.49$ G.S.T. inc.)

Married or equivalent

second member only $*(\$ 2.49$ G.S.T. inc. $)$

All other active members $*(\$ 2.49$ G.S.T. inc.)

\section{Other Memberships}

Retired members (to qualify for retired status, member must have 15 years membership in the Institute) $*(\$ 2.49$ G.S.T. inc.)

Student Members *(\$1.31 G.S.T. inc.)

Sustaining Individuals (CIF/IFC Members)

Sustaining Corporate $*(\$ 4.98$ G.S.T. inc. $)$

Upon written application, spousal members of Active Members may have the dues of one reduced by an amount determined annually. Spousal members are members of the same Section who are living together as spouses and using the same mailing address.

The Institute year runs from July 1 to June 30. Applications dated after January 1, 1993 will be charged half dues for that Institute year. Applications dated after April 1st will be charged NO DUES for that Institute year.

Section dues are in addition and range from $\$ \mathbf{5 5 . 0 0}$ to $\$ \mathbf{3 0 . 0 0}$ per Institute year.

*Note: The portion of membership which covers the cost of the Forestry Chronicle is subject to G.S.T. For tax purposes, this cost is calculated on $\$ 38.00$ which is $\$ 2.49$ G.S.T. (except Student rate of \$20.00@ @ 1.31 G.S.T.) 